\title{
Introduction to ocean floor networks and their scientific application
}

\author{
Yoshiyuki Kaneda
}

Received: 25 July 2014/Accepted: 5 August 2014/Published online: 19 August 2014

(C) Springer Science+Business Media Dordrecht 2014

This special issue is focused on ocean floor networks and their applications. Moreover, many papers relate to the applications and analyses of crustal activities and mega thrust earthquakes using real time data from underwater cable systems.

In the history of optical ocean floor cable developments, the first commercial cable was deployed in Japan in 1986 (Momma et al. 1997; Ogasawara and Kojima 2007). Since the 1990s, advanced ocean floor cables with optical amplification technologies and multi-wave length transmission systems have developed rapidly. Accordingly, scientific interest in using real time monitoring systems has expanded.

In seismology-related fields, real time monitoring is required to detect earthquakes and tsunamis as part of early warning systems (Hayashi 2010; Hoshiba and Ozaki 2012), and monitoring of crustal activity helps to better understand the mechanism of mega-thrust earthquakes (Kaneda et al. 2009a, b). To date, some advanced ocean floor network systems have been developed and deployed off the west coast of Canada/USA, Southwestern Japan and northeastern Taiwan (Chiang et al. 2010). In Japan, DONET (Dense Ocean floor Network system for Earthquakes and Tsunamis) has been developed. DONET1 was deployed around the Tonankai seismogenic zone in the Nankai Trough, while DONET2 is under deployment

Y. Kaneda $(\square)$

Disaster Mitigation Research Center Nagoya University, Furocho, Chikusa-ku, Nagoya 464-8601, Japan

e-mail: kaneda.yoshiyuki@i.mbox.nagoya-u.ac.jp

Y. Kaneda

Japan Agency of Marine Science and Technology Center,

2-15 Natsushima-cho Yokosuka 237-0061, Japan around the Nankai seismogenic zone, to the west of DONET1 (Fig. 1).

When the Mw 9 Great Earthquake occurred in East Japan on March 11 2011, the importance of real-time monitoring using ocean floor networks was recognized (Ide et al. 2011; Kido et al. 2011; Hoshiba and Ozaki 2012). Previously, tsunami experts had developed Early Warning Systems, but unfortunately they lacked enough offshore real-time monitoring data to adequately assess the magnitude of the threat (Baba et al. 2004; Tsushima et al. 2009). However, Hino and colleagues analyzed the pre-slip conditions of the 2011 Tohoku earthquake using data from pressure gauges near the epicenter (Ohta et al. 2012). The results proved to have important implications for the predictability of mega-thrust earthquakes as in the case of the Nankai Trough seismogenic zone off southwestern Japan.

Leblond et al. investigated the feasibility of estimating the volumetric flow rates of gas emissions using seafloor sensors and modeling (Greinert and Nützel 2004; Géli 2008), the results led to the high sensitivities for monitoring gas emission using advanced modeling. Kanazawa and Shinohara (2009) developed a compact ocean bottom cabled seismometer system deployed in the Japan Sea for the monitoring of seismicity. On the other hand, Takahashi et al. (2014, This special Issue) developed a new buoy observation system for tsunami and crustal deformation for EEW (Earthquake Early Warning) and its prediction, a system which is being tested as well as the quality of its produced data (Percival et al. 2011; Ohta et al. 2012). If this system proves to be of practically use, it will become a useful real time monitoring system for crustal deformations and tsunamis (Tsushima et al. 2009).

In the field of modeling and simulation research, Nakamura et al. (2011, This Special Issue) analyzed the anomalously large seismic amplification using ocean floor 


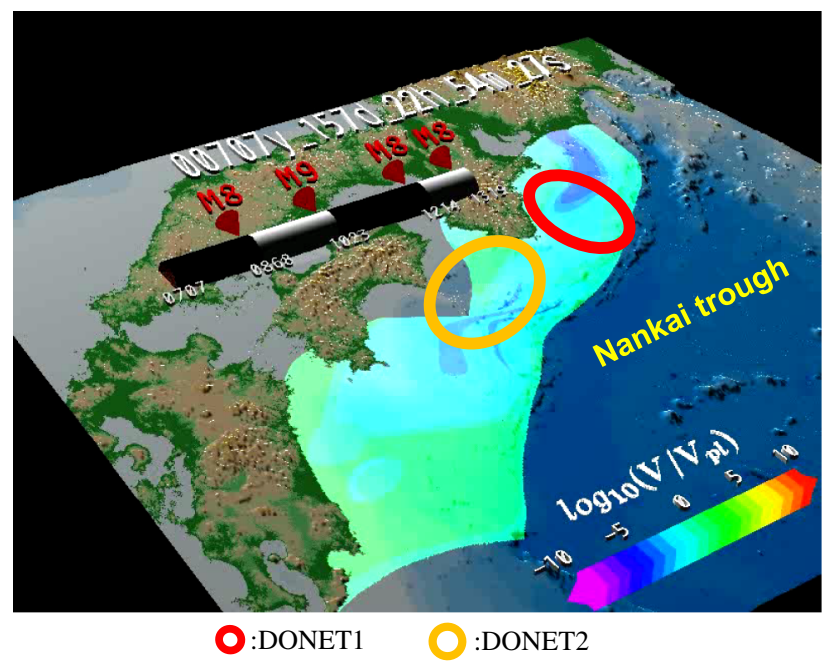

Fig. 1 The Nankai Trough seismogenic zone and ocean floor network system (Hyodo and Hori JAMSTEC) Red circle: DONET1, yellow circle: DONET2

network data from DONET1 deployed off the Eastern Kii peninsula, southwestern Japan, leading to the precise estimation of seismic magnitudes using Ocean floor network data (Park et al. 2003; Nakanishi et al. 2008; Nakamura et al. 2011).

As part of the seismological research, Nakano et al. (2012) investigated the seismicity in the Tonankai seismogenic zone off the Kii peninsula in south western Japan, detecting high seismicity and clustered seismicity for the first time in the Tonankai seismogenic zone.

Hori et al. (2013), using ocean bottom cable network data, developed a simulation geared towards the numerical forecasting of time intervals between successive M8 earthquakes along the Nankai Trough, southwestern Japan, (Ishibashi 2004; Hori 2006; Furumura 2011; Hyodo and Hori 2010, 2013; Murakami et al. 2012). This numerical experiment will also lead to the testing of numerical forecasting of mega-thrust earthquakes around the Nankai Trough seismogenic zone (Fig. 1).

Ariyoshi et al. $(2009,2012)$ investigated the detectability of shallow slow earthquakes by means of the Dense Ocean floor Network system for Earthquakes and Tsunamis (DONET1) in the Tonankai district, Japan (Nakatani 2001; Ampere and Rubin 2008). The seismicity of shallow slow earthquakes happens to be one of the indicators of the next mega-thrust earthquake recurrence on the Nankai trough seismongenic zones (Obara and Ito 2005; Nakano et al. 2012; Sugioka et al. 2012). Based on the simulation studies, it was found that the shallow part of seismicity on the mega thrust earthquake seismogenic zones will increase in the pre-seismic stage of the forthcoming recurrence of mega-thrust earthquake.
Baba et al. studied Near-field Tsunami Amplification Factors in the Kii Peninsula, using the Dense Ocean floor Network for Earthquakes and Tsunamis (DONET), contributing to the precise early estimation of tsunami scale, which is useful for disaster mitigation (Baba et al. 2004; Baba and Cummins 2005).

Hsiao et al. conducted on site analyses based on seismological observations using the Marine Cable Hosted Observatory (MACHO) off NE Taiwan (Liu et al. 1998; Lin et al. 2007; Hsu et al. 2013). The MACHO Observatory system is very similar to DONET and is used to detect the high seismicity off northeastern Taiwan;. MACHO will be extended in the near future to further improve the Early Warning System on Earthquakes and Tsunamis. Furthermore, the MACHO system will lead to the understanding of micro-seismicity and the complex tectonics off eastern Taiwan using long-term monitoring data.

Likewise, in this special issue, many experts have discussed the East Japan earthquake in 2011, which generated a large tsunami and damaged many coastal cities along the Pacific Ocean, and the possibilities of the Nankai Trough megathrust earthquake in southwestern Japan.

Previously, around the Tohoku megathrust earthquake seismogenic zone, the ratio of plate coupling appeared to be about $30 \%$, while the relative plate motion corresponding to the remaining $70 \%$ was thought to be accommodated by stable slip. As it happens, the coupling ratio has been estimated as a stable slip zone therefore, the strain accumulation has not been specifically evaluated (Fujiwara et al. 2011) even though it slowly accumulated in the estimated stable slip zones. In this particular seismogenic zone, there are only several real time monitoring systems such as the off Kamaishi small ocean floor cable system and GPS Sea level gauge buoys, which could detect the large earthquake and tsunami of the Tohoku Earthquake 2011, Nonetheless, the advanced inline cable system off Tohoku seismogenic zone is under construction which in turn will monitor the area off Tohoku and Kanto seismogenic zones for the mitigation on large earthquakes and tsunamis disasters.

It is important to highlight and to better understand crustal activities including crustal deformation, as well as for detecting earthquakes and tsunamis around submarine seismogenic zones. Extended real time monitoring systems equipped with a variety of seismometers, pressure gauges and thermometers are required in ocean seismogenic zones is most important, particularly in the circum-Pacific (Mazzotti et al. 2002; Kodaira et al. 2006; Park et al. 2003) and Indian Ocean areas as well as other locations (Pollitz et al. 2006). Furthermore, real time monitoring of ocean floor environments and processes such as gas emissions and volcanism, and monitoring systems which include chemical sensors and magnetometers and other equipment are also required in offshore areas around the world. 
In the development of future ocean floor network plans, there is a need to also develop advanced ocean floor network cable technologies, new buoys systems and data analyses/simulation studies using real time data from ocean floor networks.

Last but not least, in this special issue, many significant and important research results based on ocean observing data are also presented.

\section{References}

Ampere JP, Rubin AM (2008) Earthquake nucleation on rate state faults—aging and slip laws. J Geophys Res 113:B01302. doi:10. 1029/2007JB005082

Ariyoshi K, Hori T, Ampuero JP, Kaneda Y, Matsuzawa T, Hino R, Hasegawa A (2009) Influence of interaction between small asperities on various types of slow earthquakes in a 3-D simulation for a subduction plate boundary. Gondwana Res 16(3-4):534-544. doi:10.1016/j.gr.2009.03.006

Ariyoshi K, Matsuzawa T, Ampuero JP, Nakata R, Hori T, Kaneda Y, Hasegawa A (2012) Migration process of very low-frequency events based on a chain-reaction model and its application to the detection of preseismic slip for mega thrust earthquakes. Earth Planets Space 64(8):693-702. doi:10.5047/eps.2010.09.003

Baba T, Cummins PR (2005) Contiguous rupture areas of two Nankai earthquakes revealed by high-resolution tsunami waveform inversion. Geophys Res Lett 32:L08304. doi:10.1029/004G L022320

Baba T, Hirata K, Kaneda Y (2004) Tsunami magnitude determined from data of ocean-bottom pressure gauges around Japan. Geophys Res Lett 31: L08303. doi:10.1029/2003GL019397 C153.html. Accessed 12 Dec 2012

Chiang H-T, Shu C-T, Chang H-I, Tsao S, Chen C-X (2010) Geothermal monitoring of Kueishantao island offshore of northeastern Taiwan. Terr Atmos Ocean Sci 21:563-573. doi:10.3319/TAO.2009.11.02.01(TH

Fujiwara T, Kodaira S, No T, Kaiho Y, Takahashi N, Kaneda Y (2011) The 2011 Tohoku-oki earthquake: displacement reaching the trench axis. Science 334. doi:10.1126/science.1211554

Furumura T, Imai K, Maeda T (2011) A revised tsunami source model for the 1707 Hoei earthquake and simulation of tsunami inundation of Ryujin Lake, Kyushu, Japan. J Geophys Res 116: B02308. doi:10.1029/2010JB007918

Géli L, Henry P, Zitter T, Dupré S, Tryon M, Cagatay MN, BM de Lépinay, Le Pichon X, S, engör AMC, Görür N, Natalin B, Uçarku G, Ozeren S, Volker D, Gasperini L, Bourlange S, the Marnaut Scientific Party (2008) Gas emissions and active tectonics within the submerged section of the North Anatolian Fault zone in the Sea of Marmara. Earth Planet Sci Lett

Greinert J, Nützel B (2004) Hydroacoustic experiments to establish a method for the determination of methane bubble fluxes at cold seeps. Geo-Mar Lett 24:75-85

Hayashi Y (2010) Empirical relationship of tsunami height between offshore and coastal stations. Earth Planets Space 62:269-275

Hori T (2006) Mechanisms of separation of rupture area and variation in time interval and size of great earthquakes along the Nankai Trough, southwest Japan. J Earth Simul 5:8-19

Hori T, Miyazaki S, Hyodo M, Nakata R, Kaneda Y (2013) An earthquake forecasting system based on the sequential data assimilation of the slip on the plate boundary. Theoretical and Applied Mechanics Japan (in press)
Hoshiba M, Ozaki T (2012) Earthquake early warning and tsunami warning of JMA for the 2011 off the Pacific Coast of Tohoku earthquake (in Japanese with English Abstract). Zisin 64:155-168

Hsu S-K, Yeh Y-C, Sibuet J-C, Doo W-B, Tsai C-H (2013) A megasplay fault system and tsunami hazard in the southern Ryukyu subduction zone. Earth Planet Sci Lett 362:99-107

Hyodo M, Hori T (2010) Modeling of Nankai earthquake cycles: influence of 3D geometry of the Philippine Sea plate on seismic cycles. JAMSTEC Report R\&D 11:1-15

Hyodo M, Hori T (2013) Re-examination of possible great interpolate earthquake scenarios in the Nankai Trough, southwest Japan, based on recent findings and numerical simulations. Techtonophysics 600:175-186

Ide S, Baltay A, Beroza GC (2011) Shallow dynamic overshoot and energetic deep rupture in the $2011 \mathrm{Mw} 9.0$ Tohoku-Oki earthquake. Science 332. doi:10.1126/science. 1207020

Ishibashi K (2004) Status of historical seismology in Japan. Ann Geophys 47:339-368

Kanazawa T, Shinohara M (2009) A new, compact ocean bottom cabled seismometer system. In: Development of compact cabled seismometers for seafloor observation and a description of first installation plan. Sea Technology, pp 37-40

Kaneda Y, Kawaguchi K, Araki E, Matsumoto H, Nakamura T, Kamiya S, Ariyoshi K, Hori T (2009a) Toward understanding mega thrust earthquakes occurrence system and disaster mitigation around the Nankai trough Southwestern JapanDONET (Dense Ocean Network for Earthquakes and Tsunamis) and Next DONET. In: ICES International Symposium, $\mathrm{C} 1$, pp 27-30

Kaneda Y, Hirahara K, Furumura T (2009b) New research project for evaluating seismic linkage around the Nankai trough-integration of observation, simulation, and disaster mitigation. J Disaster Res 14:61-66

Kido M, Osada Y, Fujimoto H, Hino R, Ito Y (2011) Trench-normal variation in observed seafloor displacement associated with the 2011 Tohoku-Oki earthquake. Geophys Res Lett 38:L24303. doi:10.1029/2011GL050057

Kodaira S, Hori T, Ito A, Miura S, Fujie G, Park JO, Baba T, Sakaguchi H, Kaneda Y (2006) A cause of rupture segmentation and synchronization in the Nankai trough revealed by seismic imaging and numerical simulation. J Geophys Res 111:B09301. doi:10.1029/2005JB004030

Lin C-H, Hsu L-W, Ho M-Y, Shin T-C, Chen K-J, Yeh Y-H (2007) Low-frequency submarine volcanic swarms at the southwestern end of the Okinawa Trough. Geophys Res Lett 34:L06310. doi:10.1029/2006GL029207

Liu C-S, Liu S-Y, Lallemand S-E, Lundberg N, Reed D (1998) Digital elevation model offshore Taiwan and its tectonic implication. Terr Atmos Ocean Sci. 9:705-738

Mazzotti S, Lallemant SJ, Henry P, Le Pichon X, Tokuyama H, Takahashi N (2002) Intraplate shortening and underthrusting of a large basement ridge in the eastern Nankai subduction zone. Mar Geol 187:63-88

Momma H, Fujiwara N, Iwase R, Kawaguchi K, Suzuki S, Kinoshita $\mathrm{H}$ (1997) Monitoring system for submarine earthquakes and deep sea environment. In: Proceedings of MTS/IEEE OCEANS'97, vol 2, pp 1453-1459

Murakami A, Shuku T, Nishimura S, Fujisawa K, Nakamura K (2012) Data assimilation using the particle filter for identifying the elasto-plastic material properties of geomaterials. Int J Numer Anal Meth Geomech 37:1642-1669. doi:10.1002/nag.2125

Nakamura T, Citak SO, Takahashi N, Kaneda Y, Ohori M, Baba T (2011) A model of three dimensional seismic structure in the source area of the Tokai-Tonankai-Nankai earthquake. Abstract of Japan Geoscience Union Meeting 2011 SSS035-P32 
Nakanishi A, Kodaira S, Miura S, Ito A, Sato T, Park JO, Kido Y, Kaneda Y (2008) Detailed structural image around splay-fault branching in the Nankai subduction seismogenic zone: results from a high-density ocean bottom seismic survey. J Geophys Res 113:B03105. doi:10.1029/2007JB004974

Nakano M, Nakamura T, Kamiya S, Ohori M, Kaneda Y (2012) Intensive seismic activity around the Nankai trough revealed by DONET ocean-floor seismic observations. Earth Planets Space 65:5-15

Nakatani M (2001) Conceptual and physical clarification of rate and state friction: frictional sliding as a thermally activated rheology. J Geophys Res 106:13347-13380

Obara K, Ito Y (2005) Very low frequency earthquakes excited by the 2004 off the Kii peninsula earthquakes: a dynamic deformation process in the large accretionary prism. Earth Planets Space 57:321-326

Ogasawara Y, Kojima J (2007) Experimental results of the Real Time Simulation System(RTSS) for cable installation employing a Kalman filter algorithm, SubOptics 2007. Baltimore, USA

Ohta Y, Hino R, Inazu D, Ohzono M, Ito Y, Mishima M, Iinuma T, Nakajima J, Osada Y, Suzuki K, Fujimoto H, Tachibana K, Demachi T, Miura S (2012) Geodetic constraints on afterslip characteristics following the March 9, 2011, Sanriku-oki earthquake, Japan. Geophys Res Lett 39:L16304. doi:10.1029/ 2012GL052430
Park JO, Gregory FM, Tsuru T, Kodaira S, Kaneda Y (2003) A subducted oceanic ridge influencing the Nankai megathrust earthquake rupture. Earth Planet Sci Lett 217:77-84. doi:10. 1016/S0012-821X(03)00553-3

Percival DB, Denbo DW, Eble MC, Gica E, Mofjeld HO, Spillane MC, Tang L, Titov VV (2011) Extraction of tsunami source coefficients via inversion of DART buoy data. Nat Hazards 58. doi:10.1007/s11069-010-9688-1, 567-59

Pollitz FF, Banerjee P, Bürgmann R, Hashimoto M, Choosakul N (2006) Stress changes along the Sunda trench following the 26 December 2004 Sumatra-Andaman and 28 March 2005 Nias earthquakes. Geophys Res Lett 33:L06309. doi:10.1029/ 2005GL024558

Sugioka H, Okamoto T, Nakamura T et al (2012) Tsunamigenic potential of the shallow subduction plate boundary inferred from slow seismic slip. Nat Geosci 5:414-418. doi:10.1038/NGEO1466

Takahashi N, Ishihara Y, OCHI H1, Fukuda T, Tahara J, Maeda Y, Sugiyama T, Kido M, Ohta Y, Kogure S, Mutoh K, Hashimoto G, Kaneda Y (2014) New real-time observation buoy system for tsunami and crustal deformation. AOGS Abstract OS22-A012

Tsushima K, Hino R, Fujimoto H, Tanioka Y, Imamura F (2009) Near-field tsunami forecasting from cabled ocean bottom pressure data. J Geophys Res 114. doi:10.1029/2008JB00598 